Available online on 15.12.2019 at http://jddtonline.info
Open Access to Pharmaceutical and Medical Research
unrestricted non-commercial use, provided the original work is properly cited

Open $\odot$ Access

Research Article

\title{
Loyalty status of consumers to cigarettes brands and influencing factors in Bangalore City: A descriptive study
}

\author{
Dr Preetika Parmar, Dr. Radha \\ 1 Post Graduate Student, Department of public health dentistry, VS Dental College and hospital Bangalore India \\ 2 Professor, Department of public health dentistry, VS Dental College and hospital Bangalore India
}

\begin{abstract}
Background :- Brand loyalty has been studied in many industries and countless product categories. Despite the fact, very few research here been conducted on the tobacco product category in India. The aim of this study was to determine the loyalty status of consumers to cigarettes brands and factors that influence the loyalty status groups.

Design and methods:- A descriptive study was conducted during the period of March 2017 - April 2017 among the smokers visiting VS Dental College \& Hospital , Bangalore Karnataka. A total of 340 smokers participated in the study. Data was collected using a self administered questionnaire. Descriptive statistics with frequency and percentage was used to describe the data.
\end{abstract}

Results :- It was observed that, four main loyalty levels exist i.e. hardcore, softcore, shifters and switchers and have differe nt demographic characteristics and reasons for their loyalty status. The hardcore loyal gave their main reasons as high satisfaction derived quickly, affordable price and strong smell. The softcore reasons were; strength of the kick, similar menthol and same price.

Conclusion:- The study concluded that the loyalty status groups of smokers exist i.e. hardcore loyal, softcore loyal, shifters loyal and switchers. The reason behind the loyalty status groups is due to the nature of cigarettes and unique characteristics among the group of smokers.

Keywords: cigarettes, brand loyalty, brand switching , consumers, loyalty status.

Article Info: Received 11 Oct 2019; Review Completed 20 Nov 2019; $\quad$ Accepted 30 Nov 2019; Available online 15 Dec 2019

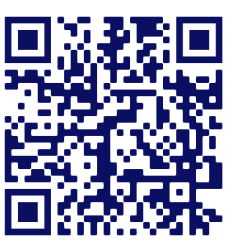

Cite this article as:

Parmar P, Radha, Loyalty status of consumers to cigarettes brands and influencing factors in Bangalore City: A descriptive study, Journal of Drug Delivery and Therapeutics. 2019; 9(6-s):143-147 http://dx.doi.org/10.22270/jddt.v9i6-s.3779

*Address for Correspondence:

Dr. Preetika Parmar, V S Dental College and Hospital Kr Road Vv Puram Bangalore

\section{INTRODUCTION:}

\section{Significance for public health :}

Smokers are found to be hardcore loyal to their brands which shows how specific they are to the brand of the cigarettes. Tobacco being the major cause of lung cancer about $60 \%$ in our country so, as public health measures the government should increase the taxes on the most preferred brands, (by the smokers(remove it) which will in turn reduce the burden of tobacco and its ill effects in our county.

American Marketing Association has defined brand loyalty as "the degree to which a customer consistently purchases the same brand within a product class". 1,2 Amine discusses two approaches to define brand loyalty: the behavioral approach and the attitudinal approach. 3 The behavioral approach suggests that a consumer's repeat purchasing of brand over time shows his or her brand loyalty. ${ }^{4}$ Jacoby and Chestnut defined brand loyalty as "the behavioral response
The attitudinal approach defines brand loyalty in terms of stated preferences, commitment or purchase intentions. 5

Brand loyalty is the hallmark for many business organizations. Many business now develop, maintain and create brand loyalty for long term profitability and source of competitive advantage. Brand loyalty has been studied in many industries and countless product categories. Despite the fact, very few research here been conducted on the tobacco product category in India.

Cigarette smoking became popular in the late 19th century, and its popularity grew constantly until the mid20 th century. When it comes to brand loyalty, smokers are well known to be extremely loyal to their brands. 6

Brand loyalty in the cigarette industry is the highest among all existing consumer products. Due to the very high loyalty in the industry, the percentage of smokers that switch from one type of cigarettes to another is very low, less than $10 \%$ every year. Firms use signs, symbols and/or 
designs which are either vocalized or non-vocalized to differentiate their brands/products from those of competing brands or products that are close substitutes.

Brand is associated with loyalty, and the extent of customer loyalty determines the rate of patronage. Consumers are either hard core loyalists to brand or switchers. Hard core brand loyalists, stick to their preferred brands, whereas brand switchers are not tied to specific brands, thus, are likely to go for available close substitutes that may provide similar satisfaction. ${ }^{7}$ When it comes to brand loyalty, smokers are well known to be extremely loyal to their brands. Cigarette product had suffered serious criticism from both medical professionals and the society at large.

Cadogan \& Foster opined that price is the most vital consideration for an average customer. ${ }^{8}$ Saced etal in their research paper - Antecedents of Cigarette brand loyalty in Pakistan revealed that there was a significant relationship between price and cigarette brand loyalty. Price is a strong driver of loyalty. Yee et al found a positive relation between brand loyalty and price. Consumers that are loyal tends to pay more for a brand. Smokers that are cigarette addict are less price sensitive. ${ }^{9}$

Hence, it is not enough to ignore research on the said product. It could be said that, there exist a gap between factors influencing loyalty and consumption. In the light of the social stigma attached to its consumption. The present study was undertaken to determine the loyalty status of consumers to cigarettes brands and factors that influence the loyalty status groups.

\section{DESIGN AND METHODS:}

Ethical clearance and informed consent: - The study has been approved by the institutional review board. All the participants gave written and verbal informed consent for participating in the study.

\section{Sample size:}

Sample size was estimated to be 340 using precision $5 \%$, power $80 \%$ and the prevalence of tobacco use $33 \% .^{10}$

\section{Study tools:}

A structured questionnaire was used to collect the primary data. The questionnaire was divided into three parts. Part A was used to determine demographic and information of the cigarettes consumers. Part B was used to capture the information of loyalty status of cigarettes consumers and Part $\mathrm{C}$ was used to generate the information on determinants of the loyalty status of cigarettes consumers. The questionnaire was validated using Lawshe's scale 11 by 5 subject experts and all the questions were found to be fulfilling the criteria.

Reliability: The reliability was tested using Cronbach's Alpha. The Cronbach's Alpha coefficient of 0.873 indicated a high reliability of the instrument.

The study was conducted during the period of 21 march - 30 April 2017 among the smokers visiting Out patient department of VS Dental College and hospital, Bangalore ,Karnataka . Patients who smoke more than 1 year were included in the study using purposive sampling.

\section{Statistical Analysis:}

The results were analyzed using SPSS, version 19(SPSS Inc. Chicago, IL, USA) . Descriptive statistics with frequencies and percentages variables were used to describe the data .

\section{RESULTS:}

The demographic characteristics of the study participants i.e. locality, Gender, Age, Marital status, Education and Incomes were analyzed to know the general classification information of cigarettes consumers. Findings are presented in table no. 1. Majority of the participants (70\%) belongs to urban locality. Male are represented by $97 \%$ and female are represented by comprised of $3 \%$. It is clearly indicated that majority of the smokers tails in the age bracket of the youth 19-35 years. This represents $43.5 \%$ of the participants. This can be explained by the fact that youth have more disposable incomes and have tendency of spending as they discover things in life.

It is indicated that participants who earn less than Rs. 10,000 per month are the majority which represents $50 \%$ of the respondents. This explains most of the cigarettes smoked are economy or value brands of cigarettes. The smoking characteristics of the study participants were analyzed and findings are presented in table no. 2 .

The results show that $24 \%$ of respondents are loyal to goldflake, Will classic 16\%, Malbauro 12\% and Benson \& Hedges $10 \%$. Others are loyal to other brands of cigarettes such as Navicut 8\% Djarum black Sweet 8\%, Charms 7\%, Bristol 7\%, others 6.8\%. (table no. 3) It was found that $71 \%$ of the respondents were hardcore loyal, $16 \%$ softcore loyal, 5\% switchers and $8 \%$ shifters loyal. Therefore majority of the smokers $71 \%$ remains hardcore loyal to only one brand of cigarettes, which they smoke.(table no. 4)

The hardcore loyal gave their main reasons as high satisfaction derived quickly, affordable price and strong smell.(table no. 5) The softcore reasons were; strength of the kick, similar menthol and same price.(table no.5 ) It is clear from the results that most smokers shift their loyalty from one brands of cigarette to another because of the various reasons. The change in tastes, Change in price was ranked second and availability, Throat irritation and chest congestion.(table no. 6)

The respondents gave reasons why they do not have loyalty to any particular brand of cigarettes like introduction of new cigarettes by competitors and change in income levels as their main reasons for switching. This was followed by out of stocks situations, increase of prices and lastly change in cigarettes features.(table no.6)

It was found that burning rate, Flavor of the brand, Satisfaction derived for smoking, Size of the filter, Strength of the kick and Design of packaging are very important while Appealing image. Brand name and Age of the brand in the market were considered to be important in determining the brand choice. Perceived quality is "the customer's perception of the overall quality or superiority of a product or service with respect to its intended purpose, relative to alternatives.(table no.6) 
Table no. 1 Demographic characteristics of study participants

\begin{tabular}{|c|c|c|}
\hline Variables & Frequency & Percentage \\
\hline \multicolumn{3}{|l|}{ Locality } \\
\hline Urban & 237 & 69.7 \\
\hline Rural & 68 & 20.0 \\
\hline Periurban & 35 & 10.3 \\
\hline \multicolumn{3}{|l|}{ Gender } \\
\hline Male & 329 & 96.8 \\
\hline Female & 11 & 3.2 \\
\hline \multicolumn{3}{|l|}{ Age } \\
\hline Below 18 yr & 46 & 13.5 \\
\hline $19-35 \mathrm{yr}$ & 148 & 43.5 \\
\hline $36-50 \mathrm{yr}$ & 101 & 29.7 \\
\hline Over 50 yr & 45 & 13.2 \\
\hline \multicolumn{3}{|l|}{ Marital status } \\
\hline Single & 126 & 37.1 \\
\hline Married & 214 & 62.9 \\
\hline \multicolumn{3}{|l|}{ Education } \\
\hline Primary & 112 & 32.9 \\
\hline Secondary & 68 & 20.0 \\
\hline College & 103 & 30.3 \\
\hline University & 34 & 10.0 \\
\hline Uneducated & 23 & 6.8 \\
\hline \multicolumn{3}{|l|}{$\begin{array}{l}\text { Income } \\
\text { rupees }\end{array}$} \\
\hline$<10,000$ & 169 & 49.7 \\
\hline $\begin{array}{ll}10,001 & - \\
20,000\end{array}$ & 92 & 27.1 \\
\hline$>20,000$ & 79 & 23.2 \\
\hline Total & 340 & 100 \\
\hline
\end{tabular}

Table no. 2 Distribution of study participants according to the smoking characteristics

\begin{tabular}{|l|l|l|}
\hline Variable & Frequency & Percentage \\
\hline $\begin{array}{l}\text { Frequency of } \\
\text { smoking in a day }\end{array}$ & & \\
\hline $1-5$ & 79 & 23.2 \\
\hline $6-10$ & 205 & 60.3 \\
\hline $11-19$ & 45 & 13.2 \\
\hline$>20$ & 11 & 3.2 \\
\hline $\begin{array}{l}\text { Money spending on } \\
\text { smoking }\end{array}$ & & \\
\hline $1-24$ rs & 66 & 19.4 \\
\hline $25-49 \mathrm{rs}$ & 48 & 14.1 \\
\hline $50-74 \mathrm{rs}$ & 136 & 40.0 \\
\hline $75-100 \mathrm{rs}$ & 66 & 19.4 \\
\hline$>100 \mathrm{rs}$ & 24 & 7.1 \\
\hline Total & 340 & 100 \\
\hline
\end{tabular}

Table no. 3 Distribution of study participants according to the favourite cigarettes

\begin{tabular}{|l|l|l|}
\hline Variable & Frequency & Percentage \\
\hline Malbauro & 42 & 12.4 \\
\hline Benson \& Hedges & 34 & 10.0 \\
\hline Goldflake & 83 & 24.4 \\
\hline Will classic & 54 & 15.9 \\
\hline Navicut & 28 & 8.2 \\
\hline Djarum black & 28 & 8.2 \\
\hline Charms & 24 & 7.1 \\
\hline Bristol & 24 & 7.1 \\
\hline Others & 23 & 6.8 \\
\hline Total & 340 & 100 \\
\hline
\end{tabular}

Table no. 4 Distribution of study participants according to the loyalty status

\begin{tabular}{|l|l|l|}
\hline Variable & Frequency & Percentage \\
\hline Hardcore loyal & 241 & 70.9 \\
\hline Softcore loyal & 54 & 16 \\
\hline Shifters & 17 & 5 \\
\hline Switchers & 28 & 8.1 \\
\hline Total & 340 & 100 \\
\hline
\end{tabular}

Table no. 5 Factors influencing hardcore loyal, softcore loyal , Shifters , switchers.

\begin{tabular}{|l|l|l|}
\hline Variable & Frequency & Percentage \\
\hline Affordable price & 33 & 9.7 \\
\hline High satisfaction derived quickly & 12 & 3.5 \\
\hline Experience with cigarettes & 11 & 3.2 \\
\hline Smell is attractive and strong & 12 & 3.5 \\
\hline High quality & 24 & 7.1 \\
\hline Heavy puff & 69 & 20.3 \\
\hline Strong kick & 13 & 3.8 \\
\hline Adequate menthol & 11 & 3.2 \\
\hline Taste & 11 & 3.2 \\
\hline Prestige & 45 & 13.2 \\
\hline Total & 241 & 100 \\
\hline softcore loyal & & \\
\hline Similar menthol taste & 12 & 22.2 \\
\hline Strength of the kick & 31 & 57.4 \\
\hline Same price & 11 & 20.3 \\
\hline Total & 54 & 100 \\
\hline Shifters & & \\
\hline Change in price & 5 & 29.4 \\
\hline Change in taste & 3 & 17.64 \\
\hline Loose tobacco & 1 & 5.8 \\
\hline Change in packaging & 2 & 11.7 \\
\hline Throat irritation & 00 & 00 \\
\hline Chest congestion & 00 & 00 \\
\hline Mentholation & 2 & 11.7 \\
\hline Availability & 4 & 23.5 \\
\hline Total & 17 & 100 \\
\hline Switchers & & \\
\hline Introduction of new cigarettes & 3 & 10.7 \\
\hline Price increases & 10 & 35.7 \\
\hline Out of stocks & 7 & 25 \\
\hline Change in cigarette features & 6 & 21.4 \\
\hline Change in income & 2 & 7.1 \\
\hline Total & 28 & 100 \\
\hline & & \\
\hline
\end{tabular}

Table no. 6 Factors influencing loyalty status

\begin{tabular}{|l|l|l|}
\hline Variable & Mean & $\begin{array}{l}\text { Standard } \\
\text { deviation }\end{array}$ \\
\hline Reasonable prices. & 2.91 & 1.270 \\
\hline Seller's product knowledge & 2.81 & 1.220 \\
\hline The package & 2.84 & 1.211 \\
\hline The level of nicotine & 2.91 & 1.270 \\
\hline The strength of the "Kick" & 2.84 & 1.211 \\
\hline The size of the filter & 2.81 & 1.220 \\
\hline The associated class & 2.809 & 1.2200 \\
\hline The aroma of the brand & 2.906 & 1.2702 \\
\hline Satisfaction derived from smoking it & 2.841 & 1.2113 \\
\hline Experience with the cigarettes & 2.841 & 1.2113 \\
\hline $\begin{array}{l}\text { Alternative available to choose } \\
\text { from. }\end{array}$ & 2.906 & 1.2702 \\
\hline The brand name & 2.841 & 1.2113 \\
\hline Occupation & 2.841 & 1.2113 \\
\hline
\end{tabular}




\section{DISCUSSION:}

It was observed that, the four main loyalty levels exist i.e. hardcore, softcore, shifters and switchers and have different demographic characteristics. The reasons for their loyalty status are hardcore loyalty are: high satisfaction derived quickly, affordable price and strong smell and for the softcore loyalty, strength of the kick, similar menthol and same price, which is in accordance with McCarthy etal.

Are there reasons for shifters and switchers?

It was also observed that the following five factors were the most important to the loyalty status groups in influencing the choice of the cigarettes to smoke in order of importance.

(To hardcore loyal; Availability of cigarettes, Information about the brands, Level of Nicotine, Income of smokers and Satisfaction derived from smoking. To softcore loyal; Strength of the kick, Availability of the cigarettes, Experience with the cigarettes, Performance of the Brand and Burning rate of the cigarettes in accordance with Aaker etal $^{12}$, and Joseph et al. ${ }^{13}$

Majority of the smokers tails in the age bracket of the youth(young adulthood) 19-35 years. This can be explained by the fact that youth have more disposable incomes and have tendency of spending as they discover things in life. Participants who earn less than Rs. 10,000 are the majority smokers. This explains most of the cigarettes smoked are economy or value brands of cigarettes .

It was found that the most favourite commonly used brand was goldflake and majority of them were loyal to one brand of cigarette, this was because of high satisfaction derived from smoking, affordable price, high quality, adequate menthol, and taste. This compares well with Giathi 14 findings that showed that the reasons for brand loyalty were because of satisfaction derived from smoking, affordable price and strong smell.

The reasons for purchasing two or more brands consistently were because of Strength of the kick and similar taste. This can be explained by the fact that smokers share loyalty to the cigarette they smoke so long as they have similar strength of the kick and taste and this depends on the experience they have with cigarettes. It was established that burning rate, Flavor of the brand, Satisfaction derived from smoking, Size of the filter, Strength of the kick and Design of packaging are very important while Appealing image. Brand name and Age of the brand in the market were considered to be important in determining the brand choice. Perceived quality is "the customer's perception of the overall quality or superiority of a product or service with respect to its intended purpose, relative to alternatives" which is in accordance with Aaker etal. 15

Consumers have a perception of the overall quality of a brand that is not necessarily based on knowledge of its detailed specifications. Perceived quality of the brands and the characteristics of a given product directly influences purchase decisions and brand loyalty, especially when a buyer is not motivated or able to conduct a detailed analysis. It can also support a premium price, which, in turn, can create profits that can be reinvested in brand equity. Further, characteristics and the quality of the product can be the basis for a brand extension If a brand is well regarded in one context, the assumption will be that it will have high quality in a related context.

The study established that price is a very important factor in determining the brand choice while Gabor $\mathbf{1 6}$ observed that consumers response to prices vary depending upon the kind of pricing strategies applied and not the extent to which consumers perceives prices correctly.

The Place variable had one factor, Availability / Accessibility which was perceived to be important. The above results to a large extent agree with the general determinants of brand choice; the type of the brand should be readily available in all selling outlets, points of sales in order to increase loyalty. Motivation, which had three factors, Satisfaction derived from smoking, Assael $(1998)^{17}$ states that motivation can be negative or positive in direction. It is therefore important to note that both positive and negative motivational forces are similar in that they serve to imitate and sustain human behavior. Perception had two factors, Information about the brand and Belief held about the product Both factors were considered to be important in brand choice.

This study may have been affected by the limitations like firstly the study was conducted only in one hospital setting. The smokers' characteristics may differ from others areas. Secondly the small size of the sample could have limited confidence in results. Thirdly the study used pre-determined questions which may have limited the respondents from bringing out other relevant issues, which the researcher may have not mentioned. This might limit generalization of the results to other situations.

\section{CONCLUSION:}

The study concluded that, loyalty status exists among group of smokers i.e. hardcore loyal, soft-core loyal, shifters loyal and switchers. The reason behind the loyalty status groups is due to the nature of cigarettes and unique characteristics of the group of smokers. The reasons for brand loyalty were high satisfaction derived from smoking, affordable price, high quality, adequate menthol, and taste. While reason for purchasing two or more brands consistently were because of Strength of the kick and similar taste. The following factors are considered to influence brand choice to a large extent, Price, Product, Place, Motivation, Perception, Attitude and Personal Factors. Ciggarette brands do exhibit high loyalty compared to other consumer categories and shows a trend to higher brand loyalty.

\section{RECOMMENDATION :-}

1. Increased in taxes on cigarette and other tobacco products will reduce its consumption

2. Reduction in tar/nicotine content in cigarette need to be encouraged.

3. Government, World Health Organization (WHO), and non- governmental agencies should increase sensitization on the hazards of cigarette smoking.

\section{SUGGESTIONS FOR FURTHER RESEARCH}

The following were suggested as possible topics for further research:

(1) There is need to carry out a nationwide survey on the loyalty status groups and factors that influence them in making a choice of the brand of cigarettes to smoke. This can help in establishing national norms.

(2) There is need to replicate the current study and include a larger sample.

(3) A study should be carried out to establish the contributions of the different factors on the different loyalty status groups. 
(4) The study was broad and dealt with many different factors that influence the loyalty status. It may be possible to categorize the factors and study the loyalty status groups independently. This may help to give a deeper understanding of the individual loyalty groups.

(5) There is need to carry' out a study with controls to establish if it is the various factors that cause the different smokers loyalty status groups.

\section{REFERENCES:}

1. Delgado, B.E. and Munuera, A.J.L. Brand Trust in the Context of Consumer Loyalty, Euro J Mark. 2001; 35(11):1238-1258.

2. Dick, A.S. and Basu, K. Customer Loyalty towards an Integrated Framework. Journal of the Academy of Marketing Science. 1994; 22(2): 99-113.

3. Amine, A. Consumers' True Brand Loyalty: The Central Role of Commitment. Journal of Strategic Marketing. 1998; 6:305-319

4. Keller, K.L. Strategic Brand Management: Building, Measuring, and Managing Brand Equity, 3rd Edition, 2009; Pearson Education Inc. and Dorling Kindersley Publishing Inc.

5. Jacoby, J. and Chestnut, R.W. Brand Loyalty: Measurement and Management. New York. 1978.

6. Saeed, R. Tafail, M. S., Lodhi, r. N., Ahmed, M., Arshad, H. M. \& Saeed, R. Antecedents of cigarette brand loyalty in Pakistan. Journal of Basic and Applied Scientific Research. 2003; 3(5):969-975

7. McCarthy, E. J. and Perreault, W. D. Jr. Essentials of marketing.1991; Boston: Irwin.

8. Yee, W. F. \& Sidek, Y. Influence of brand loyalty on consumer sportwear. International Journal of Economics and Management. 2008; 2 (2): 221-236.
9. Cadogan, J. W. \& Foster, B. D. Relationship selling and customer loyalty: An empirical investigation, marketing intelligence and planning, 2001; 18:189-199.

10. Kozlowski, L. T., Rickert, W. S., Pope, M. A., Robinson, J. C. \& Frecker, R. C. Estimating the yield to smokers of tar, nicotine and carbon monoxide from the "lowest yield" ventilated filter-cigarettes. British Journal Addict. 1982; 77:159-165

11. Wilson FR, Pan W, Schumsky DA. Recalculation of the critical values for Lawshe's content validity ratio. Measurement and Evaluation in Counseling and Development. 2012; 45(3):197210.

12. Aaker, D. Building Strong Brands. 1996; The Free Press, New York.

13. Nyadighibe, Joseph , Amaechi. Ezekiel, Maurice Sunday ,Awara, Nsobiari Festus . Consumers' Brand Loyalty And Cigarette Consumption In Calabar, Cross River State, Nigeria. Elk Asia Pacific Journal of Marketing And Retail Management. 2014; 5(4) DOI: 10.16962/EAPJMRM/issn.2349-2317/2014.

14. Giathi, J C. "A survey of loyalty status of consumers to various cigarettes brands in Nairobi". Unpublished MBA Project, University of Nairobi. 2004

15. Aaker D A. "Managing Brand Equity, Capitalizing on the value of the Brand Name”, 1991: Newyork, Free Press.

16. Gabor, Andre, pricing, London: Heinemann educational books : 1977

17. Assael, H. Consumer Behavior and Marketing Action, 6th Edition. 1998. Cincinatti, Ohio: South Western College Publishing. 